\title{
Anti-diabetes and Anti-inflammatory Activities of Phenolic Glycosides from Liparis odorata
}

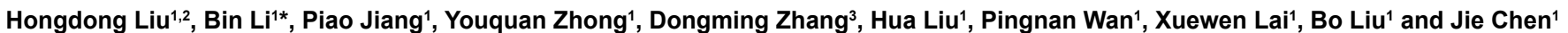

${ }^{1}$ Pharmacy College, Jiangxi University of Traditional Chinese Medicine, 818 Xinwan Road, Nanchang 330004, Jiangxi, PR China

${ }^{2}$ Technology Center, Jiangzhong Group, 618 Huoju Road, Nanchang 330096, Jiangxi, PR China

${ }^{3}$ Institute of Materia Medica, Chinese Academy of Medical Sciences and Peking Union Medical College, Beijing 100050, PR China

\begin{abstract}
Five new phenolic glycosides, liparisglycoside K-O (1-5) and one known compound, 4-allyl-2,6-dimethoxyphenol glucoside (6) were isolated from the whole plant of Liparis odorata. Compound $\mathbf{6}$ was isolated and identified from this genus for the first time. The structures of all compounds were elucidated through extensive spectroscopic methods including UV, IR, MS, 1D- and 2D-NMR. All compounds from Liparis odorata were evaluated for their ability to inhibit LPS-induced NO production on the BV2 microglial cell line in vitro, as well as their inhibitory effects on PTP1B and $\alpha$-glucosidase enzyme assays.
\end{abstract}

Keywords: Liparis odorata; Orchidaceae; Phenolic glycosides; Antiinflammatory activity; Anti-diabetes effect

\section{Introduction}

Lipariso dorata (Willd.) Lindl., belonging to the Orchid family [1], is an herbaceous plant widely distributed in southern China, and usually used to inhibit inflammation and reduce lipid in Jiangxi province folk medicine in China. Through our continuous interest in the chemical and biologically active constituents of this plant [2-4], five new phenolic glycosides (Figure 1) were isolated and their structures elucidated through extensive spectroscopic analyses, as well as literature comparisons. In addition, one known compound was isolated and identified as 4-allyl-2,6-dimethoxyphenol glucoside [5]. To the best of our knowledge, obesity therapy using phenolic glycoside derivatives has not been studied yet, and we here reportthe anti-diabetes effects against protein tyrosine phosphatase $1 \mathrm{~B}$ (PTP1B) and $\alpha$-glucosidase enzymes for all the isolated compounds. PTP1B plays a critical role as a key negative regulator of the insulin and leptin signaling pathways, thereby regulating glucose homeostasis and body weight, respectively [6], while $\alpha$-glucosidase inhibition is critical for the early treatment of diabetes mellitus [7]. Therefore, effective inhibition of both enzymesis a potential therapy for both type 2 diabetes mellitus and obesity.

\section{Materials and Methods}

\section{General experimental procedures}

Ultraviolet (UV) spectra were recorded using a Shimadzu UV-300 spectrophotometer. IR spectra were recorded on a Nicolet 5700 FTIR spectrometer by a transmission microscope method. HR-ESI-MS results were obtained using an Agilent 1100 series LC/MSD Trap SL mass spectrometer. Optical rotations were measured on a Perkin Elmer 241 automatic digital polarimeter. The 1D- and 2D-NMR spectra were recorded using INOVA 500 and Mercury-400 spectrometers in dimethyl sulfoxide- $d_{6}\left(\mathrm{DMSO}-d_{6}\right)$. GC was conducted on an Agilent Technologies 7890A instrument. Preparative highpressure liquid chromatography (HPLC) was carried out on a Shimadzu LC-6AD instrument with an SPD-20A detector, using a YMC-Pack ODS-A column $(250 \times 20 \mathrm{~mm}, 5 \mu \mathrm{m})$. Column chromatography (CC) was performed using silica gel (200-300 mesh, Qingdao Marine Chemical Inc., Qingdao, China), ODS gel (50 $\mu \mathrm{m}$, YMC, Japan) and PRP-512A macroporous resin (100-200 mesh). Thin layer chromatography (TLC) was performed with glass pre-coated silica gel $\left(\mathrm{GF}_{254}\right)$ plates. Spots were visualized by UV light $(254 \mathrm{~nm})$ or spraying with $10 \% \mathrm{H}_{2} \mathrm{SO}_{4}$ in ethanol (EtOH)followed by heating.

\section{Plant material}

L. odorata was collected in the Jiangxi province of China in August 2012. The plant materials were identified by professor Lai Xuewen, Jiangxi University of Traditional Chinese Medicine in China, where a voucher specimen (No. 002017) was deposited.

\section{Extraction and isolation}

The whole air-dried plant of $L$. odorata $(30.0 \mathrm{~kg})$ was extracted three times under reflux with $95 \% \mathrm{EtOH}$ at ambient temperature. After removing the organic solvent under reduced pressure, the $95 \%$ EtOH extract of $L$. odorata was dissolved in $0.2 \mathrm{M} \mathrm{HCl}$. The HCl-soluble fraction was basified by $\mathrm{NH}_{3} \cdot \mathrm{H}_{2} \mathrm{O}$ to $\mathrm{pH} 10.0$ and then extracted three times in succession with chloroform, EtOAc and $\mathrm{n}-\mathrm{BuOH}$, respectively. The $\mathrm{n}-\mathrm{BuOH}$ fraction $(100.0 \mathrm{~g})$ was subjected to macroporous resin CC (PRP-512A, $\varnothing 10 \times 50 \mathrm{~cm}$ ) and eluted with a gradient of EtOH in water $(30-95 \% \mathrm{EtOH})$. The $70 \% \mathrm{EtOH}$ eluate $(1.8 \mathrm{~g})$ was further subjected to reversed-phase chromatography using a C18 silica gel column $(\varnothing$ $2.0 \times 60 \mathrm{~cm})$ with gradient mixtures of $\mathrm{CH}_{3} \mathrm{OH}-\mathrm{H}_{2} \mathrm{O}(30: 100-100: 0)$ as eluents to yield five fractions (A-E). Fraction C $(800.0 \mathrm{mg})$ was applied to a silica gel column $(\varnothing 2.0 \times 60 \mathrm{~cm})$ and eluted with $\mathrm{CHCl}_{3}-\mathrm{MeOH}$ $(50: 1,25: 1,15: 1,10: 1,5: 1,2: 1,1: 1,0: 1)$ to yield 8 subfractions $\left(C_{1}-C_{8}\right)$ based on TLC analysis.

Subfraction $\mathrm{C}_{2}(50.0 \mathrm{mg})$ was chromatographed on a silica gel column $(\varnothing 1.2 \times 50 \mathrm{~cm})$ using $\mathrm{CHCl}_{3}-\mathrm{MeOH}(15: 1)$ and purified by preparative HPLC with $\mathrm{MeOH}-\mathrm{H}_{2} \mathrm{O}(45: 55,8.0 \mathrm{~mL} / \mathrm{min})$ to give compound 6 (11.0 mg). Subfraction $\mathrm{C}_{3}(150 \mathrm{mg})$ was chromatographed using a Sephadex LH-20 column $(\varnothing 1.5 \times 200 \mathrm{~cm})$ eluting with $\mathrm{MeOH}$, then further purified by preparative HPLC and eluted with $\mathrm{MeOH}-\mathrm{H}_{2} \mathrm{O}$ $(68: 32,8.0 \mathrm{~mL} / \mathrm{min})$ to yield compound $\mathbf{5}(105.0 \mathrm{mg})$ and compound 4 $(6.0 \mathrm{mg})$. Subfraction $\mathrm{C}_{6}(62.0 \mathrm{mg})$ was purified with preparative HPLC eluting with $\mathrm{MeOH}-\mathrm{H}_{2} \mathrm{O}(60: 40,8.0 \mathrm{~mL} / \mathrm{min})$ to yield compound 1

*Corresponding author: Bin Li, Pharmacy College, Jiangxi University of Traditional Chinese Medicine, 818 Xinwan Road, Nanchang 330004, Jiangxi, PR China, Tel: 8679187118827; Fax: 8679187118825; E-mail: Ibin@jzjt.com

Received July 06, 2016; Accepted July 14, 2016; Published July 20, 2016

Citation: Liu H, Li B, Jiang P, Zhong Y, Zhang D, et al. (2016) Anti-diabetes and Anti-inflammatory Activities of Phenolic Glycosides from Liparis odorata. Med chem (Los Angeles) 6: 500-505. doi:10.4172/2161-0444.1000390

Copyright: (c) 2016 Liu H, et al. This is an open-access article distributed under the terms of the Creative Commons Attribution License, which permits unrestricted use, distribution, and reproduction in any medium, provided the original author and source are credited. 


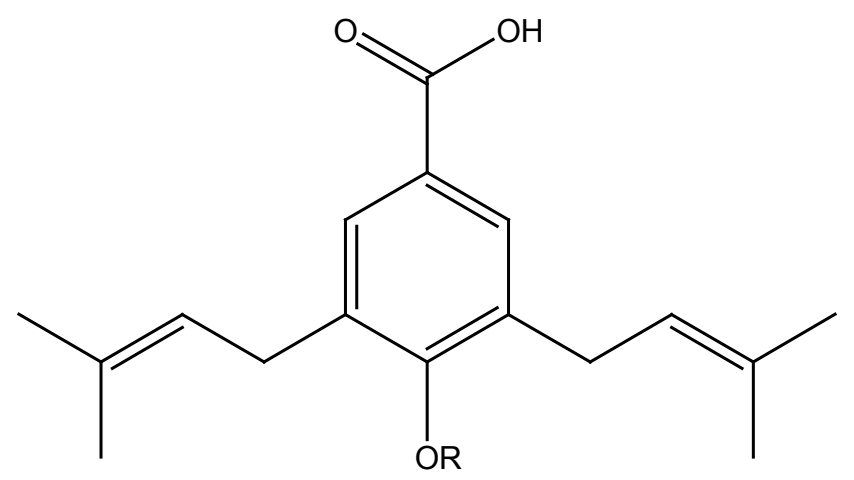

$\mathrm{R}$

$\begin{array}{ll}\text { 1 } & \text { A } \\ 2 & \text { B } \\ 3 & \text { C } \\ 4 & \text { D } \\ \text { 5 } & \text { E }\end{array}$

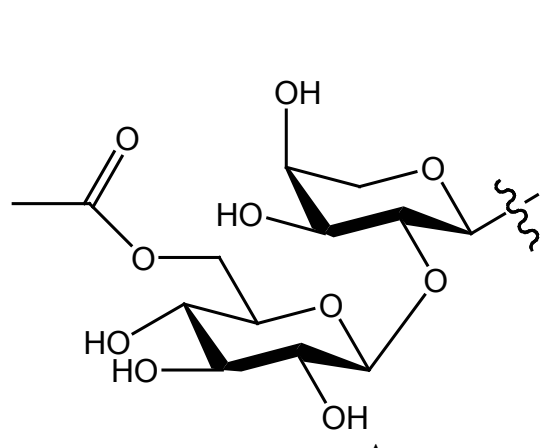

A

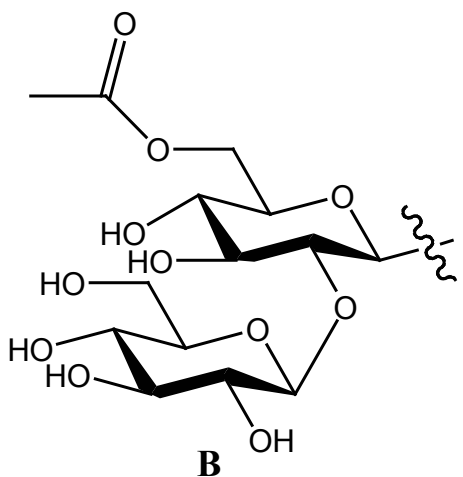

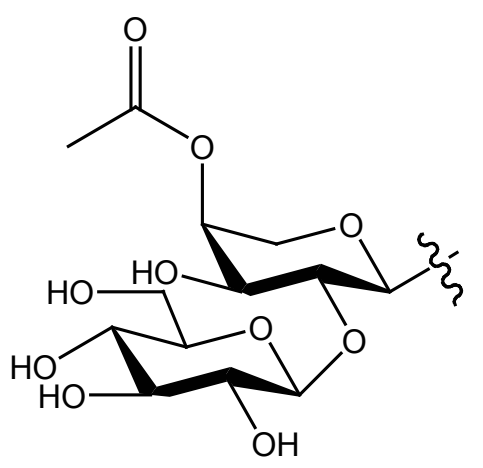

C

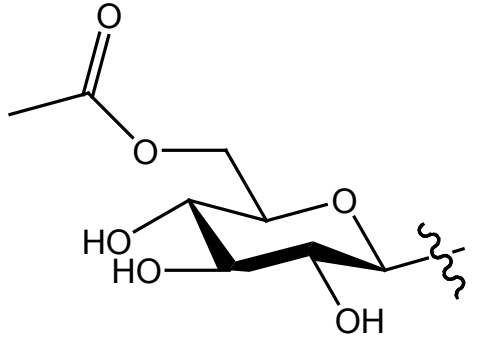

D

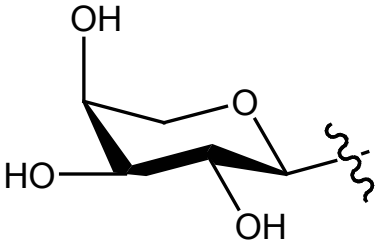

E

Figure 1: Chemical structures of 1-5.

(21.0 $\mathrm{mg})$, and subfraction $\mathrm{C}_{7}(79.0 \mathrm{mg}$ ) was purified by preparative HPLC with $\mathrm{MeOH}-\mathrm{H}_{2} \mathrm{O}(60: 40,8.0 \mathrm{~mL} / \mathrm{min})$ to yield compound $3(2.5$ $\mathrm{mg})$. Finally, subfraction $\mathrm{C}_{8}(82 \mathrm{mg})$ was subjected to a reversed-phase C18 silica gel column and eluted with $\mathrm{MeOH}-\mathrm{H}_{2} \mathrm{O}(15: 85,30: 70,50: 50$, $75: 25,100: 0)$. Then, the $75 \%$ eluate was further separated by repeated preparative HPLC with $55 \% \mathrm{MeOH}$ at a flow rate of $8 \mathrm{~mL} / \mathrm{min}$ to yield compound $2(8.0 \mathrm{mg})$.

Liparisglycoside K (1): Colorless oil; [a]20 D: +23.6 (c 1.0, $\mathrm{MeOH}) ; \mathrm{UV}(\mathrm{MeOH}) \lambda_{\max }(\log \varepsilon): 209(4.31), 242(3.97) \mathrm{nm} ; \mathrm{IR}(\mathrm{KBr})$ $v_{\max }: 3376,2973,2916,1681,1426,1378,1190,1042,954 \mathrm{~cm}^{-1}$; ${ }^{1} \mathrm{H}$ NMR (DMSO-d, $500 \mathrm{MHz}$ ) and ${ }^{13} \mathrm{CNMR}\left(\mathrm{DMSO}-\mathrm{d}_{6}, 125 \mathrm{MHz}\right.$ ) data (see
Tables 1 and 2); HR-ESI-MS m/z $610.2632[\mathrm{M}]^{+}\left(\right.$Calcd for $\mathrm{C}_{30} \mathrm{H}_{42} \mathrm{O}_{13}$, 610.2625).

Liparisglycoside L (2): White amorphous power; [a]20 D: +10.2 (c 1.10, MeOH); UV(MeOH) $\lambda_{\max }(\log \varepsilon): 208(4.34), 241(3.79) \mathrm{nm}$; $\mathrm{IR}(\mathrm{KBr}) v_{\max }: 3370,2969,2928,1714,1601,1553,1424,1250,1095,961$ $\mathrm{cm}^{-1} ;{ }^{1} \mathrm{H}$ (DMSO-d, $500 \mathrm{MHz}$ ) and ${ }^{13} \mathrm{C}$ NMR (DMSO-d, $125 \mathrm{MHz}$ ) data (see Tables 1 and 2); HR-ESI-MS m/z 640.2729 [M] ${ }^{+}$(Calcd. for $\mathrm{C}_{31} \mathrm{H}_{44} \mathrm{O}_{14}, 640.2731$ ).

Liparisglycoside M (3): Colorless oil; [a]20 D: +23.6 (c 1.0, $\mathrm{MeOH}) ; \mathrm{UV}(\mathrm{MeOH}) \lambda_{\max }(\log \varepsilon): 209(4.31), 242(3.97) \mathrm{nm} ; \mathrm{IR}(\mathrm{KBr})$ $v_{\max } 3359,2969,2926,1679,1424,1378,1250,1135,1080,936 \mathrm{~cm}^{-1}$; 
Citation: Liu H, Li B, Jiang P, Zhong Y, Zhang D, et al. (2016) Anti-diabetes and Anti-inflammatory Activities of Phenolic Glycosides from Liparis odorata. Med chem (Los Angeles) 6: 500-505. doi:10.4172/2161-0444.1000390

${ }^{1} \mathrm{H}$ NMR (DMSO-d, $500 \mathrm{MHz}$ ) and ${ }^{13} \mathrm{C}$ NMR (DMSO-d, $125 \mathrm{MHz}$ ) data (see Tables 1 and 2); HR-ESI-MS $\mathrm{m} / \mathrm{z} 610.2630[\mathrm{M}]^{+}$(Calcd. for $\left.\mathrm{C}_{30} \mathrm{H}_{42} \mathrm{O}_{13}, 610.2625\right)$.

Liparisglycoside $\mathbf{N}(4)$ : White amorphous power; [a]20 D: -20.8 (c 1.0, MeOH); UV(MeOH) $\lambda_{\max }(\log \varepsilon): 208(4.24), 240(3.81) \mathrm{nm}$; $\mathrm{IR}(\mathrm{KBr}) v_{\max }: 3362,2971,2927,1715,1601,1428,1380,1271,1190,910$ $\mathrm{cm}^{-1} ;{ }^{1} \mathrm{H}$ NMR (DMSO-d $\mathrm{d}_{6}, 400 \mathrm{MHz}$ ) and ${ }^{13} \mathrm{C}$ NMR(DMSO-d, 100 $\mathrm{MHz}$ ) data (see Tables 1 and 2); HR-ESI-MS m/z $478.2202[\mathrm{M}]^{+}(\mathrm{Calcd}$ for $\mathrm{C}_{25} \mathrm{H}_{34} \mathrm{O}_{9}, 478.2203$ ).

Liparisglycoside $\mathbf{O}(5)$ : White amorphous power; [a]20 D: +63.8 (c 0.95, MeOH); UV(MeOH) $\lambda_{\max }$ (loge): 208 (4.39), 242 (3.87) nm; $\operatorname{IR}(\mathrm{KBr}) v_{\max }: 3358,2974,2924,1691,1545,1424,1382,1189,1150,953$ $\mathrm{cm}^{-1}$; ${ }^{1} \mathrm{H}$ NMR (DMSO-d, $500 \mathrm{MHz}$ ) and ${ }^{13} \mathrm{C}$ NMR (DMSO-d, 125 $\mathrm{MHz}$ ) data (see Tables 1 and 2); HR-ESI-MS m/z $406.1993[\mathrm{M}]^{+}($calcd for $\mathrm{C}_{22} \mathrm{H}_{30} \mathrm{O}_{7}, 406.1992$ ).

Anti-diabetes and anti-inflammatory assays: As previous studies showed that phenolic glycosides compounds from Liparis odorata possessed anti-inflammatory activities [3], so, these new phenolic glycosides in this paper were also evaluated activities to inhibit inflammation. Also because of new compounds, widespread screening on activities were looked forward to, thus evaluation of these compounds for their protein tyrosine phosphatase $1 \mathrm{~B}$ inhibition and a-glucosidase inhibition activities were untaken in our experiments, seeking new potential drugs for the clinic.

Protein tyrosine phosphatase $1 \mathrm{~B}$ inhibition: The assay was carried out as previously described [8]. Briefly, all samples were dissolved in $100 \%$ DMSO. $p$-Nitrophenyl phosphate ( $p$-NPP, $2 \mathrm{mM}$ ) and PTP1B (0.05-0.1 $\mu \mathrm{g}$ ) were added to a buffer containing $50 \mathrm{mM}$ citrate ( $\mathrm{pH} 6.0$ ), $1 \mathrm{mM}$ EDTA, $0.1 \mathrm{M} \mathrm{NaCl}$, and $1 \mathrm{mM}$ dithiothreitol, with or without test sample. Following incubation at $37^{\circ} \mathrm{C}$ for $30 \mathrm{~min}$, the reaction was terminated by adding $10 \mathrm{M} \mathrm{NaOH}(10 \mu \mathrm{L})$. The amount of released produced $p$-nitrophenol ( $p$-NP) was estimated by measuring the absorbance at $405 \mathrm{~nm}$. The measured values were corrected for nonenzymatic hydrolysis of $2 \mathrm{mM} p$-NP by measuring the increase in absorbance at $405 \mathrm{~nm}$ in the absence of the PTP1B enzyme.

$\boldsymbol{\alpha}$-Glucosidase inhibition: $\alpha$-Glucosidase inhibitory activity was determined according to a previously reported method [9]. Briefly, for each compound, the extract was premixed with $p$-nitrophenyl glucopyranoside ( $p$-NPG) $(2 \mathrm{mM})$ as a substrate in $2 \mathrm{~mL} 0.1 \mathrm{M}$ phosphate buffer $(\mathrm{pH}=6.86)$. Then, $\alpha$-glucosidase ( 0.05 units) was added to the mixture to start the reaction. The reaction was incubated at $37 \pm 0.5^{\circ} \mathrm{C}$ for $15 \mathrm{~min}$ and stopped with $4 \mathrm{~mL}$ of $0.1 \mathrm{M} \mathrm{Na}_{2} \mathrm{CO}_{3}$. The $\alpha$-glucosidase inhibitory activity was determined by measuring the absorbance at $400 \mathrm{~nm}$ as an indication for $p$-NP produced from $p$-NPG.

Anti-inflammatory activity: The murine microglial BV2 cell lines were purchased from the Cell Culture Centre at the Institute of Basic Medical Sciences, Chinese Academy of Medical Sciences. LPS (from Escherichia coli 055: B5), were obtained from Sigma-Aldrich. The inhibitory activity of extracted compounds on LPS-stimulated NO production in BV2 cells was measured as described previously [3].

\section{Results and Discussion}

Liparis odorata is was widely used as a folk medicine to inhibit inflammation and reduce lipid in China, through our continuous interests in the bioactive constituents of this plant [2-4], on the basis of pharmacological action tracking method, systematically studies on the chemical compositions and bioactivities of Liparis odorata were carried out, looking for new biological compounds.

Compound 1, a colorless solid, was assigned a molecular formula of $\mathrm{C}_{30} \mathrm{H}_{42} \mathrm{O}_{13}$ determined by high-resolution electrospray ionization mass spectrometry (HR-ESI-MS) of its quasi-molecular ion peak at $\mathrm{m} / \mathrm{z} 610.2632[\mathrm{M}]^{+}$(calcd. for 610.2625). The ${ }^{1} \mathrm{H}$ NMR spectrum (Table 1) displays the signals attributable to two aromatic protons at $\delta_{\mathrm{H}} 7.54$ (s, H-2, 6), two olefinic protons at $\delta_{\mathrm{H}} 5.24(\mathrm{t}, J=8.5 \mathrm{~Hz}, \mathrm{H}-8 / 13)$, two methylene protons at $\delta_{\mathrm{H}} 3.45(\mathrm{~m}, \mathrm{H}-7 / 12)$, and four methyl protons at $\delta_{\mathrm{H}} 1.68(\mathrm{~s}, \mathrm{H}-10 / 15)$ and 1.71 (s, H-11/16). The ${ }^{13} \mathrm{C}$ NMR (Table 2) and HSQC spectra exhibited signals for two aromatic methenyl carbons at $\delta_{\mathrm{C}} 128.5(\mathrm{C}-2,6)$, and four quaternary carbons at $\delta_{\mathrm{C}} 156.6(\mathrm{C}-4), \delta_{\mathrm{C}}$ $135.2(\mathrm{C}-3 / 5)$ and $\delta_{\mathrm{C}} 126.5(\mathrm{C}-1)$, all indicating a meta-tetrasubstituted benzene ring. $\mathrm{HMBC}$ spectroscopy correlationswere observed from $\mathrm{H}-2 / 6\left(\delta_{\mathrm{H}} 7.54\right)$ with carbonyl carbon $\left(\delta_{\mathrm{C}} 167.2, \mathrm{C}-17\right)$, suggesting that the carbonyl group was attached to C-1 $(\delta 126.5)$. The HMBC spectrum exhibited long-range correlations of $\mathrm{H}-7 / 12\left(\delta_{\mathrm{H}} 3.45\right)$ with C-2/6 ( $\delta$ 128.5), C-3/5 ( $\delta$ 135.2), C-9/14 ( $\delta$ 132.2) and C-4 $(\delta$ 156.6), indicating that there were two prenyl groups attached to the benzene

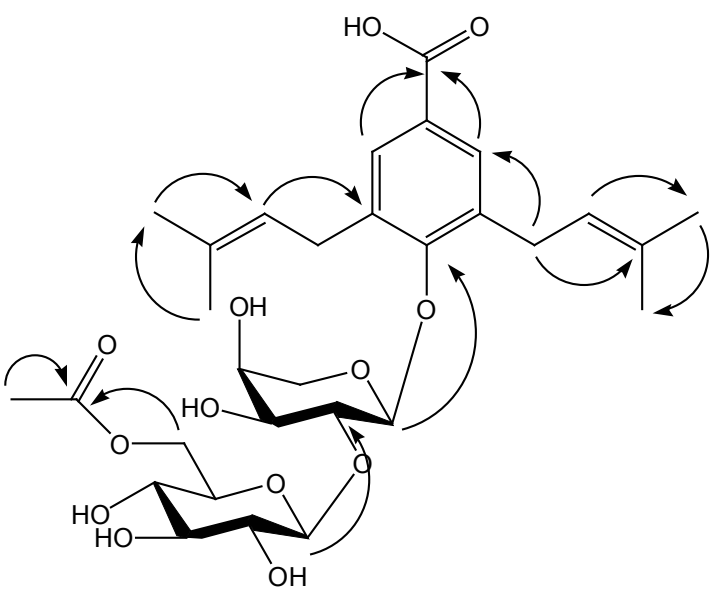

1

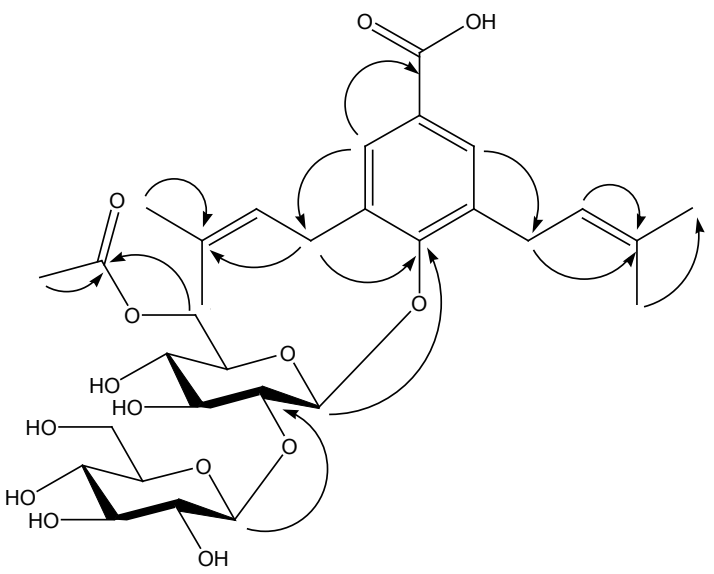

2

Figure 2: HMBC and key correlations of compounds 1 and 2. 
Citation: Liu H, Li B, Jiang P, Zhong Y, Zhang D, et al. (2016) Anti-diabetes and Anti-inflammatory Activities of Phenolic Glycosides from Liparis odorata. Med chem (Los Angeles) 6: 500-505. doi:10.4172/2161-0444.1000390

\begin{tabular}{|c|c|c|c|c|c|}
\hline $\mathbf{H}$ & $1^{a}$ & $2^{a}$ & $3^{a}$ & $4^{b}$ & $5^{a}$ \\
\hline $2 / 6$ & $7.54 \mathrm{~s}$ & $7.55 \mathrm{~s}$ & $7.55 \mathrm{~s}$ & $7.55 \mathrm{~s}$ & $7.55 \mathrm{~s}$ \\
\hline $7 / 12$ & $3.45 \mathrm{~m}$ & $3.43 \mathrm{~m}$ & $3.46 \mathrm{~d}(7.5)$ & $3.48 \mathrm{~m}$ & $3.49 \mathrm{~m}$ \\
\hline $8 / 13$ & $5.24 \mathrm{t}(8.5)$ & $5.22 \mathrm{t}(7.0)$ & $5.26 \mathrm{t}(7.5)$ & $5.24 \mathrm{~m}$ & $5.24 \mathrm{t}(7.5)$ \\
\hline $10 / 15$ & $1.68 \mathrm{~s}$ & $1.68 \mathrm{~s}$ & $1.69 \mathrm{~s}$ & $1.68 \mathrm{~s}$ & $1.69 \mathrm{~s}$ \\
\hline \multirow[t]{2}{*}{$11 / 16$} & $1.71 \mathrm{~s}$ & $1.71 \mathrm{~s}$ & $1.71 \mathrm{~s}$ & $1.71 \mathrm{~s}$ & $1.72 \mathrm{~s}$ \\
\hline & Ara & Gluc & Ara & Gluc & Ara \\
\hline $1^{\prime}$ & $4.72 \mathrm{~d}(6.0)$ & $4.69 \mathrm{~d}(7.5)$ & $4.81 \mathrm{~d}(6.0)$ & $4.62 d(7.6)$ & $4.50 \mathrm{~d}(7.5)$ \\
\hline $2^{\prime}$ & $3.95 \mathrm{~m}$ & $3.43 \mathrm{~m}$ & $3.94 \mathrm{~m}$ & $3.33 \mathrm{~m}$ & $3.66 \mathrm{~m}$ \\
\hline $3^{\prime}$ & $373 \mathrm{~m}$ & $3.49 \mathrm{~m}$ & $3.81 \mathrm{~m}$ & $3.24 \mathrm{~m}$ & $3.40 \mathrm{~m}$ \\
\hline $4^{\prime}$ & $3.73 \mathrm{~m}$ & $3.43 \mathrm{~m}$ & $4.16 \mathrm{~m}$ & $3.19 \mathrm{~m}$ & $3.64 \mathrm{~m}$ \\
\hline $5^{\prime}$ & $\begin{array}{l}3.77 \mathrm{~m} \\
3.36 \mathrm{~m}\end{array}$ & $3.55 \mathrm{~m}$ & $\begin{array}{l}3.61 \mathrm{~m} \\
3.94 \mathrm{~m}\end{array}$ & $3.45 \mathrm{~m}$ & $\begin{array}{l}3.16 \mathrm{~m} \\
3.69 \mathrm{~m}\end{array}$ \\
\hline $6^{\prime}$ & - & $\begin{array}{l}4.25 \text { overlapped } \\
4.25 \text { overlapped }\end{array}$ & - & $\begin{array}{l}4.05 \mathrm{~m} \\
4.15 \mathrm{~m}\end{array}$ & \\
\hline \multirow[t]{2}{*}{$\mathrm{CH}_{3} \mathrm{CO}-$} & - & $1.89 \mathrm{~s}$ & $2.08 \mathrm{~s}$ & $1.89 \mathrm{~s}$ & \\
\hline & Gluc & Gluc & Gluc & & \\
\hline $1 "$ & $4.46 \mathrm{~d}(7.5)$ & $4.25 \mathrm{~d}(6.5)$ & $4.53 d(8.0)$ & & \\
\hline $2 "$ & $3.18 \mathrm{~m}$ & $3.13 \mathrm{~m}$ & $3.09 \mathrm{~m}$ & & \\
\hline $3 "$ & $3.05 \mathrm{~m}$ & $2.96 \mathrm{~m}$ & $3.04 \mathrm{~m}$ & & \\
\hline $4 "$ & $3.05 \mathrm{~m}$ & $3.03 \mathrm{~m}$ & $3.09 \mathrm{~m}$ & & \\
\hline $5 "$ & $3.33 \mathrm{~m}$ & $3.22 \mathrm{~m}$ & $3.17 \mathrm{~m}$ & & \\
\hline $6 "$ & $\begin{array}{l}3.93 \mathrm{~m} \\
4.15 \mathrm{~m}\end{array}$ & $\begin{array}{l}3.70 \mathrm{~m} \\
3.39 \mathrm{~m}\end{array}$ & $\begin{array}{l}3.41 \mathrm{~m} \\
3.52 \mathrm{~m}\end{array}$ & & \\
\hline $\mathrm{CH}_{3} \mathrm{CO}-$ & $1.62 \mathrm{~s}$ & - & - & & \\
\hline
\end{tabular}

a-Date in DMSO-d6 (500 MHz, $\delta$ in ppm, $\mathrm{J}$ in Hz); ${ }^{b}$-Date in DMSO-d6 (400 MHz, $\delta$ in ppm, J in Hz)

Table 1: ${ }^{1} \mathrm{H}$ NMR Spectroscopic Data of Compounds 1-5.

\begin{tabular}{|c|c|c|c|c|c|}
\hline Position & Compound 1 & Compound 2 & Compound 3 & Compound 4 & Compound 5 \\
\hline 1 & 126.5 & 126.9 & 126.7 & 126.8 & 126.6 \\
\hline $2 / 6$ & 128.5 & 128.5 & 128.5 & 128.5 & 128.6 \\
\hline $3 / 5$ & 135.2 & 135.5 & 135.3 & 135.4 & 135.4 \\
\hline 4 & 156.6 & 156.0 & 156.2 & 156.0 & 156.3 \\
\hline $7 / 12$ & 28.1 & 27.9 & 28.2 & 27.8 & 28.1 \\
\hline $8 / 13$ & 122.7 & 122.8 & 122.7 & 122.8 & 122.8 \\
\hline $9 / 14$ & 132.2 & 132.2 & 132.1 & 132.2 & 132.2 \\
\hline $10 / 15$ & 17.9 & 17.8 & 17.8 & 17.8 & 17.9 \\
\hline $11 / 16$ & 25.7 & 25.6 & 25.6 & 25.6 & 25.6 \\
\hline \multirow[t]{2}{*}{17} & 167.2 & 167.1 & 167.1 & 167.2 & 167.2 \\
\hline & Ara & Gluc & Ara & Gluc & Ara \\
\hline $1^{\prime}$ & 102.8 & 104.0 & 102.6 & 104.4 & 105.5 \\
\hline $2^{\prime}$ & 80.5 & 80.4 & 79.8 & 73.4 & 71.2 \\
\hline $3^{\prime}$ & 71.2 & 74.5 & 70.1 & 76.1 & 72.6 \\
\hline $4^{\prime}$ & 66.5 & 73.8 & 69.8 & 69.8 & 67.8 \\
\hline $5^{\prime}$ & 64.9 & 71.6 & 62.4 & 74.0 & 66.5 \\
\hline $6^{\prime}$ & & 63.0 & & 63.4 & \\
\hline$\underline{\mathrm{C}} \mathrm{H}_{3} \mathrm{CO}$ & & 20.5 & 21.0 & 20.5 & \\
\hline \multirow[t]{2}{*}{$\mathrm{CH}_{3} \underline{\mathrm{CO}}$} & & 170.0 & 170.0 & 170.2 & \\
\hline & Gluc & Gluc & Gluc & & \\
\hline $1^{\prime \prime}$ & 104.8 & 103.3 & 104.2 & & \\
\hline $2^{\prime \prime}$ & 76.2 & 76.5 & 76.5 & & \\
\hline $3^{\prime \prime}$ & 74.5 & 73.3 & 74.5 & & \\
\hline $4^{\prime \prime}$ & 70.1 & 70.1 & 70.1 & & \\
\hline $5 "$ & 73.9 & 77.0 & 77.0 & & \\
\hline $6^{\prime \prime}$ & 63.9 & 61.1 & 61.2 & & \\
\hline$\underline{\mathrm{C}}_{3} \mathrm{CO}$ & 20.0 & & & & \\
\hline $\mathrm{CH}_{3} \underline{\mathrm{CO}}$ & 170.2 & & & & \\
\hline
\end{tabular}

${ }^{a}$ Date were measured in DMSO- $d 6(125 \mathrm{MHz}, \delta$ in ppm)

Table 2: ${ }^{13} \mathrm{C}$ NMR data for compounds $1-5$ a. 
ring at C-3 and C-5 [2-3]. The 2D-NMR spectra (Figure 2) showed the presence of an acetyl group at $\delta_{\mathrm{H}} 1.62(3 \mathrm{H}, \mathrm{s}), \delta_{\mathrm{C}} 170.2$ and $\delta_{\mathrm{C}} 20.0$, this group was assigned to C-6" ( $\left.\delta_{\mathrm{C}} 63.9\right)$ from the HMBC crosspeak of H-6" ( $\delta_{\mathrm{H}} 4.15$ and $\left.\delta_{\mathrm{H}} 3.93\right)$ with the acetyl group $\left(\delta_{\mathrm{C}} 170.2\right)$. Next, the proton resonances of the sugar units were observed, and their hydrolyzed products were identified as $\alpha$-L-arabinose and $\beta$-Dglucose by gas chromatography. In the HMBC spectrum, long-range correlations were observed of Ara H-1' $(\delta$ 4.72) with C-4 $(\delta$ 156.6), and Glc H-1" ( $\delta 4.46)$ with Ara C-2' $(\delta 80.5)$, indicating that the sugar moiety was located at C-4 of the aglycone unit. The spectral data were similar to the known compound methyl-3,5-bis(3-methyl-2-butenyl)4-O-[ $\beta$-D-glucopyranosyl- $(1 \rightarrow 2)-\alpha$-L-arabinopyranosyl] benzoate $[10]$, except for the major difference in the presence of an additional acetyl group assigned to C-6". Consequently, the structure of compound 1 was confirmed as 4-O-[a-L-arabinopyranosyl- $(1 \rightarrow 2)-6$ "-O-acetyl- $\beta$ - $D$ glucopyranosyl]-3,5-bis(3-methyl-2-butenyl) benzoic acid (Figure 1) and named liparisglycoside $\mathrm{K}(\mathbf{1})$.

Compound 2 was obtained as a white amorphous powder. Its molecular formula was deduced as $\mathrm{C}_{31} \mathrm{H}_{44} \mathrm{NaO}_{14}$ from HR-ESI-MS at $\mathrm{m} / \mathrm{z} 663.2622[\mathrm{M}+\mathrm{Na}]^{+}$(calcd. for $\mathrm{C}_{31} \mathrm{H}_{44} \mathrm{NaO}_{14}, 633.2518$ ). The ${ }^{1} \mathrm{H}$ (Table 1) and ${ }^{13} \mathrm{C}$ NMR date (Table 2) of 2 showed a close structural similarity to the aglycone moiety of compound $\mathbf{1}$, indicating that the major differences were in their sugar moieties. Aided by $2 \mathrm{D}-\mathrm{NMR}$ analysis (Figure 2) of $\mathbf{2}$, one acetyl and two glucopyranosyl groups were confirmed. In $\mathrm{HMBC}$ data, long-range correlations were observed from Gluc H-1' $\left(\delta_{\mathrm{H}} 4.69\right)$ with C-4 $\left(\delta_{\mathrm{C}} 156.0\right)$, and Gluc H-1" $\left(\delta_{\mathrm{H}} 4.25\right)$ with Gluc C-2' $\left(\delta_{\mathrm{C}} 80.4\right)$, and the carbonyl carbons of the acetyl $\delta_{\mathrm{C}} 170.0$ with Gluc $\mathrm{H}-6$ " $\left(\delta_{\mathrm{H}} 4.25\right)$, indicating that the acetyl unit was located at C-6' of the first Glc unit. The sugar residues were identified as two $\beta$-D-glucopyranosyl groups by $\mathrm{GC}$ of the hydrolyzed product. Thus, structure 2 was determined to be 4-O-[6'-O-acetyl- $\beta$-D-glucopyranosyl$(1 \rightarrow 2)-\beta$-D-glucopyranosyl]-3,5-bis(3-methyl-2-butenyl) benzoic acid, and the compound was named liparisglycoside $\mathrm{L}(\mathbf{2})$.

Compound 3 was isolated as colorless oil. Its molecular formula was established as $\mathrm{C}_{30} \mathrm{H}_{42} \mathrm{O}_{13}$ by analysis of the HR-ESI-MS spectrum at $\mathrm{m} / \mathrm{z} 633.2522[\mathrm{M}+\mathrm{Na}]^{+}\left(\right.$calcd. for $\left.\mathrm{C}_{30} \mathrm{H}_{42} \mathrm{O}_{13}, 633.2518\right)$. The ${ }^{1} \mathrm{H}$ (Table 1) and ${ }^{13} \mathrm{C}$ NMR data (Table 2) of 3 were comparable to those of 1 and 2, showing that the main differences were in the sugar part and the location of the acetoxy (OAc) group. Connectivity of the OAc group was established from the HMBC spectrum, which showed a correlation between Ara H-4' $\left(\delta_{\mathrm{H}} 4.16\right)$ and the carboxyl carbon of the acetyl unit $\left(\delta_{C} 170.0\right)$. Hence, the OAc group was located at C- 4 ' of the Ara. Moreover, the sugar residues were identified as $\alpha$-L-arabinose and $\beta$-D-glucose by GC of the hydrolyzed product. So the structure of 3 was established as 4-O-[4'-O-acetyl- $\alpha$-L-arabinopyranosyl- $(1 \rightarrow 2)-\beta-D$ glucopyranosyl]-3,5-bis(3-methyl-2-butenyl) benzoic acid, which was named liparisglycoside $\mathrm{M}(\mathbf{3})$.

Compound 4 was obtained as a white amorphous powder. Its molecular formula was determined to be $\mathrm{C}_{25} \mathrm{H}_{34} \mathrm{O}_{9}$ by HR-ESI-MS at $\mathrm{m} / \mathrm{z} 501.2094[\mathrm{M}+\mathrm{Na}]^{+}$(calcd. for $\mathrm{C}_{25} \mathrm{H}_{34} \mathrm{NaO}_{9}, 501.2095$ ). The ${ }^{1} \mathrm{H}$ (Table 1) and ${ }^{13} \mathrm{C}$ NMR data (Table 2) revealed that compound 4 was structurally very similar to compound $\mathbf{1}$, but the molecular weight of compound $\mathbf{4}$ was 132 less than compound $\mathbf{1}$ due to the absence of an arabinose. The acetyl group $\left[\delta_{\mathrm{H}} 1.89(3 \mathrm{H}, \mathrm{s}) ; \delta_{\mathrm{C}} 170.2,20.5\right]$ was located at C-6', determined by the HMBC correlation of $\mathrm{H}^{-} 6^{\prime}\left(\delta_{\mathrm{H}} 4.15,4.05\right)$ with $\mathrm{C}=\mathrm{O}\left(\delta_{\mathrm{C}} 170.2\right)$ (Figure 2$)$, while the sugar residue was identified as $\beta$-D-glucopyranose by GC of the hydrolyzed product. Therefore compound 4 was established as $4-O-\left(6^{\prime}-O\right.$-acetyl- $\beta$-D-glucopyranosyl)3,5-bis(3-methyl-2-butenyl) benzoic acid, named liparisglycoside $\mathrm{N}(4)$.
Compound 5, obtained as a white amorphous power, was assigned the molecular formula of $\mathrm{C}_{22} \mathrm{H}_{30} \mathrm{O}_{7}$ via HR-ESI-MS at $\mathrm{m} / \mathrm{z} 429.1885$ $[\mathrm{M}+\mathrm{Na}]^{+}$(calcd. for $\mathrm{C}_{22} \mathrm{H}_{30} \mathrm{O}_{7}, 429.1884$ ). Analysis of the ${ }^{1} \mathrm{H}$ (Table 1) and ${ }^{13} \mathrm{C}$-NMR spectra (Table 2) indicated that compound 5 also possessed a structure similar to compound $\mathbf{1}$ and that the major differences between them were the absence of the acetyl group and glucose. The sugar residue was identified as $\alpha$-L-arabinose by GC of the hydrolyzed product. Therefore, the structure of compound $\mathbf{5}$ was determined to be 4-O-(a-L-arabinopyranosyl)-3,5-bis(3-methyl-2butenyl) benzoic acid, named liparisglycoside $\mathrm{O}$ (5).

The biological activity of the above compounds 1-6, isolated from Liparis odorata, was tested by individual evaluation of their in vitro hypolipidemic activity against $\alpha$-glucosidase and PTP1B enzymes. The results are summarized in Table 3 . Only compound $\mathbf{3}$ showed inhibitory activity (9.7\% of PTP1B and $6.1 \%$ of $\alpha$-glucosidase), other compounds didn't have significant effects. As the structure of compound $\mathbf{3}$ is different from other compounds by the existence of an acetoxy (OAc) group linking to the C-4 of Arabinose, and maybe it was the reason to have such bioactivities. In addition, the compounds were evaluated in vitro for their inhibition (\%) of lipopolysaccharide (LPS)-stimulated nitric oxide (NO) production in BV2 microglial cells using the Griess reagent. As shown in Table 4, all compounds were found to possess weak inhibitory activity.

\section{Conclusions}

In summary, five new phenolic glycosides (1-5), along with one known compounds (6) were isolated from $L$. odorata. We found only compound $\mathbf{3}$ showed weak inhibitory activity against $\alpha$-glucosidase and PTP1B enzymes and all the compounds possessed anti-inflammatory effects by inhibition the NO production in LPS-activated BV2 microglial cells. Further studies on the action mechanism of phenolic glycosides compounds of Liparis odorata were taken in our laboratory, it was better to expand the usage of this ancient and effective folk medicine.

\section{Conflict of Interest}

The authors confirm that this article content has no conflict of interest.

\begin{tabular}{|c|c|c|c|}
\hline Compound $^{\mathbf{a}}$ & $\begin{array}{c}\text { Concentration } \\
(\boldsymbol{\mu} \mathbf{M})\end{array}$ & $\begin{array}{c}\text { Inhibition (\%) of } \\
\text { PTP1B }\end{array}$ & $\begin{array}{c}\text { Inhibition(\%) of } \\
\boldsymbol{\alpha} \text {-Glucosidase }\end{array}$ \\
\hline $\mathbf{1}$ & 10 & 0.2 & -5.1 \\
\hline $\mathbf{2}$ & 10 & 2.5 & -8.2 \\
\hline $\mathbf{3}$ & 10 & 9.7 & 6.1 \\
\hline $\mathbf{4}$ & 10 & 3.2 & 5.5 \\
\hline $\mathbf{5}$ & 10 & -0.2 & 8.0 \\
\hline $\mathbf{6}$ & 10 & 9.5 & -6.3 \\
\hline
\end{tabular}

aThe purities of compounds for assay were purified by HPLC over $95 \%$

Table 3: Inhibitory effects of isolated compounds 1-6 on PTP1B enzyme and a-Glucosidase.

\begin{tabular}{|c|c|c|}
\hline Compounds & Concentration (Mol/L) & Inhibition (\%) \\
\hline $\mathbf{1}$ & $10^{-5}$ & 20.43 \\
\hline $\mathbf{2}$ & $10^{-5}$ & 1.11 \\
\hline $\mathbf{3}$ & $10^{-5}$ & 20.30 \\
\hline $\mathbf{4}$ & $10^{-5}$ & 15.05 \\
\hline $\mathbf{5}$ & $10^{-5}$ & 19.89 \\
\hline $\mathbf{6}$ & $10^{-5}$ & 19.56 \\
\hline Curcumin $^{\mathrm{a}}$ & $10^{-5}$ & 62.16 \\
\hline
\end{tabular}

aPositive control

Table 4: Inhibitory activities on LPS-induced NO production in BV2 of compounds 1-6. 
Citation: Liu H, Li B, Jiang P, Zhong Y, Zhang D, et al. (2016) Anti-diabetes and Anti-inflammatory Activities of Phenolic Glycosides from Liparis odorata. Med chem (Los Angeles) 6: 500-505. doi:10.4172/2161-0444.1000390

\section{Acknowledgements}

The authors are grateful to the National Natural Science Foundation of China (No.81260629), the Jiangxi province young scientist training fund (Jing gang star item, 2008-222), the Jiangxi province major fund of Education Ministry (GJJ12515), and the Jiangxi province fund of Medical Ministry (2009A056).

\section{References}

1. Chinese materia medica editorial board of State Administration of Traditional Chinese Medicine (1999) Chinese materiamedica (VI). Shanghai Science Press, Shanghai, p: 737.

2. Li B, Liu HD, Zhang DM, Lai XW, Liu B, et al. (2014) Three new bioactive phenolic glycosides from Liparisodorata. Nat Prod Res 28: 522-529.

3. Xie YH, Yu SH, Liu HD, Zhang DM, Lai XW, et al. (2015) Anti-inflammatory phenolic glycosides from Liparisodorata. Med Chem Res 24: 356-361.

4. Jiang P, Liu HD, Xu XH, Liu B, Zhang DM, et al. (2015) Three new alkaloids and three new phenoliglycosides from Liparisodorata. Fitoterapia 107: 63-68.
5. Miyase T, Kuroyanagi M, Noro T, Ueno A, Fukushima S (1985) Studies on sesquiterpenes from Macroclinidium trilobum Makino II. Chem Pharm Bull 33 $4445-4450$.

6. Johnson TO, Ermolieff J, Jirousek MR (2002) Protein tyrosinephosphatase 1B inhibitors for diabetes. Nat Rev Drug Disc 1: 696-709.

7. Laar FVD, Lucassen P, Akkermans RP, Lisdonk EHVD, Rutten G, et al. (2005) Alpha-glucosidase inhibitors fortype 2 diabetesmellitus. Cochrane Database Syst Rev 2 CD003639.

8. Cui L, Thuong PT, Lee HS, Ndinteh DT, Mbafor JT, et al. (2008) Flavanones from the stem bark of Erythrinaabyssinica. Bioorg Med Chem 16: 10356-10362.

9. Matui T, Ueda T, Sugita K, Terahara N, Matsumoto K (2001) Alpha-Glucosidase inhibitory action ofnatural acylatedanthocyanins. 1. Survey of natural pigments with potent inhibitory activity. J Agric Food Chem 49: 1948-1951.

10. Huang S, Pan MF, Zhou XL, Zhou ZL, Wang CJ, et al. (2013) Five newnervogenic acid derivatives from Liparisnervosa. Chin Chem Lett 24: 734-736. 